\title{
Chromosome mapping of 5S rRNA genes differentiates Brazilian populations of Leporellus vittatus (Anostomidae, Characiformes)
}

\author{
Cecilia Teixeira de Aguilar ${ }^{1}$ and Pedro Manoel Galetti Junior ${ }^{2}$ \\ ${ }^{1}$ Departamento de Genética, Instituto de Biologia, Universidade Federal do Rio de Janeiro, \\ Rio de Janeiro, RJ, Brazil. \\ ${ }^{2}$ Departamento de Genética e Evolução, Universidade Federal de São Carlos, São Carlos, SP, Brazil.
}

\begin{abstract}
Among the anostomid fishes, the genus Leporellus is represented by only three species: L. nattereri, endemic of the Amazon River, L. retropinnis, endemic of the Piracicaba River, and L. vittatus, widely distributed in rivers from Peru, Colombia, Guianas, and different major hydrographic basins of Brazil. A cytogenetic study carried out on specimens of Leporellus vittatus from three major Brazilian hydrographic basins evidenced a karyotype of 54 metacentric and submetacentric chromosomes. C-banding analysis revealed the presence of large pericentromeric heterochromatic segments in all chromosomes and a telomeric block coincident with the NOR sites. $\mathrm{Ag}, \mathrm{CMA}_{3}$ or MM staining, and FISH with ribosomal probes located the $45 \mathrm{~S}$ ribosomal genes on the terminal region of the long arm of the $12^{\text {th }}$ chromosome pair of all populations. Nevertheless, in the specimens from the Paraná and São Francisco Basins the $5 \mathrm{~S}$ rDNA clusters were interstitially located by FISH on the long arm of the $2^{\text {nd }}$ chromosome pair, while in the specimens from the Tocantins-Araguaia Basin these sites were observed on the long arm of the $9^{\text {th }}$ chromosome pair and on the short arm of the $17^{\text {th }}$ chromosome pair. These data suggest that the species currently named Leporellus vittatus may comprise a complex of cryptic species.
\end{abstract}

Key words: karyotype, C-bands, 45S rDNA, 5S rDNA.

Received: August 30, 2006; Accepted:July 10, 2007.

\section{Introduction}

The Anostomidae family comprises 12 genera of typically Neotropical fishes, occurring from Central America to South America (Garavello and Britski, 2003). According to the current taxonomic classification, based on morphological characters, the genus Leporellus is the smallest one of this family, represented by only three species: $L$. nattereri, endemic of the Amazon River (Northern Brazil), L. retropinnis, endemic of the Piracicaba River (Southeastern Brazil), and L. vittatus, widely distributed in rivers from Peru, Colombia, Guianas, and three major Brazilian hydrographic basins: Paraná, São Francisco and Tocantins-Araguaia (Fowler, 1950; Garavello and Britski, 2003).

Nevertheless, there is little agreement as to the limits of the genus. The wide geographical distribution of $L$. vittatus has raised questions about the cospecificity of local populations of this species. As the major drainage basins of Brazil began to develop during the Tertiary (Buerlen, 1970)

Send correspondence to Cecilia Teixeira de Aguilar. Departamento de Genética, Instituto de Biologia, Universidade Federal do Rio de Janeiro, Bloco A, Cidade Universitária, Ilha do Fundão, 21941-590 Rio de Janeiro, RJ, Brazil. E-mail: aguilar@acd.ufrj.br. and several teleost fish species of the families Cichlidae, Characidae, and Curimatidae have already been described as endemic of distinct hydrographic basins (Kullander, 1983; Menezes, 1988; Vari, 1988), it is possible that, due to the limited gene flow, some populations have genetically diverged, although the conservative morphology prevents the detection of such differentiation. Therefore, the species known as Leporellus vittatus may be actually representing a complex of species.

Classical population models of chromosome evolution have postulated that small and/or restricted populations may show a higher karyotypic diversity than migratory and/or large populations, which seem to retain more conservative karyotypes, at least at the macrostructure level (Lande, 1979).

Previous cytogenetic studies have determined the diploid number, the constitutive heterochromatin distribution pattern (C-bands), and the location of the nucleolus organizer regions (NORs) by silver-staining on specimens of just one population of $L$. vittatus from the Paraná Basin (Galetti et al., 1991).

In view of these considerations, the aim of the present study was to investigate the possible geographical variation 
of Leporellus vittatus through cytogenetic comparisons. Samples collected in three major Brazilian hydrographic basins were cytogenetically analyzed and Giemsa karyotypes, C-banding patterns, and ribosomal DNA sites (rDNA) studied by silver staining, base-specific fluorochromes (chromomycin $\mathrm{A}_{3}$ or mithramycin, and 4',6diamidino-2-phenylindole) and fluorescence in situ hybridization were investigated in order to find potential chromosome markers.

\section{Material and Methods}

\section{Sampling sites}

Samples of Leporellus vittatus representing three distinct populations of major Brazilian hydrographic basins were collected. Seventeen specimens from the MogiGuaçu River, Pirassununga, São Paulo State (21 ${ }^{\circ}$ 9' S and $47^{\circ} 4^{\prime}$ W), Paraná Basin, Southeastern Brazil; four from the São Francisco River, Três Marias, Minas Gerais State $\left(18^{\circ} 2^{\prime} \mathrm{S}\right.$ and $\left.45^{\circ} 2^{\prime} \mathrm{W}\right)$, São Francisco Basin, Southeastern Brazil; and three from the Araguaia River, Barra do Garças, Mato Grosso State (15 9' $\mathrm{S}$ and $52^{\circ} 3^{\prime} \mathrm{W}$ ), Araguaia-Tocantins Basin, Central Brazil were analyzed (Figure 1).

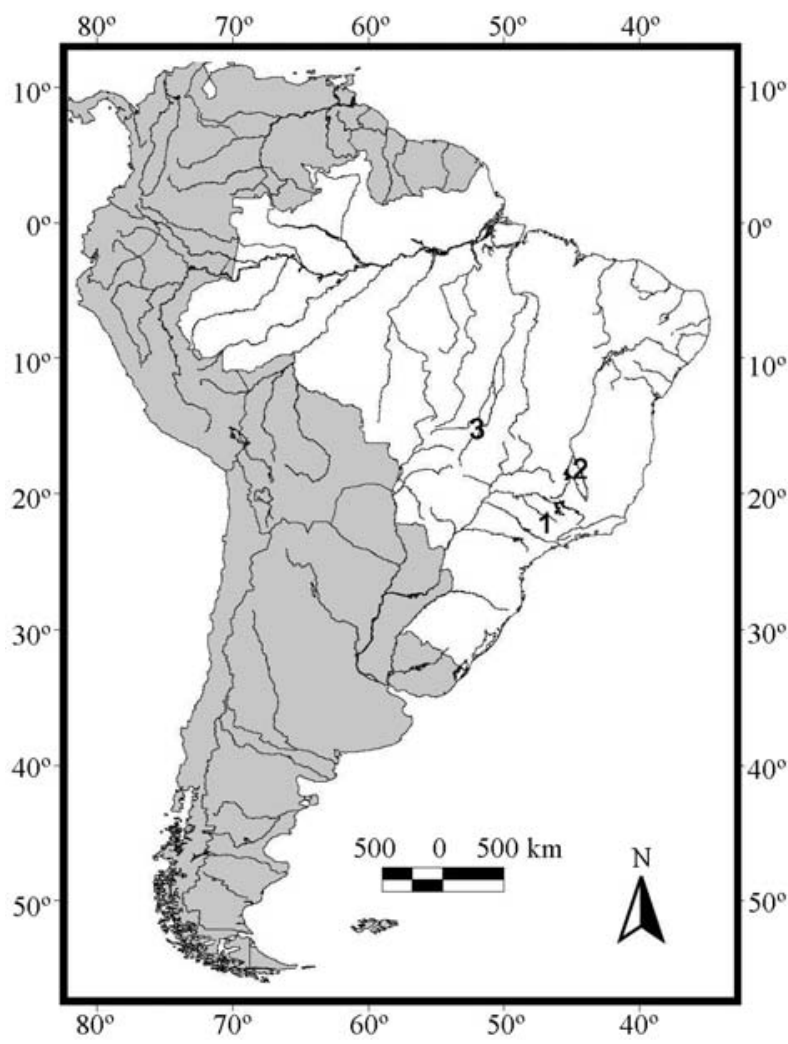

Figure 1 - Collection sites of Leporellus vittatus: Mogi-Guaçu River, Pirassununga - Paraná Basin (1); São Francisco River, Três Marias - São Francisco Basin (2); Araguaia River, Barra do Garças - Tocantins-Araguaia Basin (3).

\section{Chromosome staining techniques}

Mitotic chromosomes were obtained from kidney cellular suspensions through the air-drying technique (Bertollo et al., 1978) or, alternatively, by short term solid tissue culture (Fenocchio et al., 1991). Giemsa karyotypes were established for the three populations. The constitutive heterochromatin distribution pattern was investigated by barium hydroxide treatment (Sumner, 1972). The nucleolus organizer regions (Ag-NORs) were observed by colloidal silver-staining (Howell and Black, 1980). Fluorochrome staining with the $\mathrm{GC}$-specific chromomycin $\mathrm{A}_{3}\left(\mathrm{CMA}_{3}\right)$ or mithramycin (MM), and the AT-specific 4',6-diamidino2-phenylindole (DAPI) was carried as described by Schmid (1980) and Schweizer (1978), respectively.

\section{Fluorescence in situ hybridization}

Fluorescence in situ hybridization (FISH) was performed basically according to Pinkel et al. (1986), using a cocktail of $18 \mathrm{~S}$ and $28 \mathrm{~S}$ cloned fragments of the rDNA of Xenopus laevis (Cortadas and Pavon, 1982), and a 5S rDNA probe of the fish Leporinus elongatus, obtained by PCR (polymerase chain reaction) as described in Martins and Galetti (1999). The probes were labeled with biotin-16-dUTP by nick translation. The metaphase chromosome slides were incubated with RNase $(40 \mu \mathrm{g} / \mathrm{mL})$ for $1.5 \mathrm{~h}$ at $37^{\circ} \mathrm{C}$ in a moist chamber. The chromosomal DNA was denatured for $5 \mathrm{~min}$ at $70{ }^{\circ} \mathrm{C}$ in a solution of $70 \%$ formamide in $2 \times \mathrm{SSC}$. After that, $40 \mu \mathrm{L}$ of hybridization mixture $(1 \mu \mathrm{g}$ of denatured probe, $50 \%$ formamide, and $10 \%$ dextran sulphate in $2 \times \mathrm{SSC}$ ) were applied to the slides under a glass coverslip. The hybridization was performed overnight at $37^{\circ} \mathrm{C}$ in a moist chamber. The slides were then washed three times at $37{ }^{\circ} \mathrm{C}$, once in a solution of $50 \%$ formamide in $2 \times \mathrm{SSC}$, and twice in $2 \times \mathrm{SSC}$, for $15 \mathrm{~min}$ each. The probes were detected by avidin-FITC conjugate. The signal was enhanced by biotinylated anti-avidin and avidin-FITC. Afterwards, the chromosomes were counterstained with $70 \mu \mathrm{L}$ of propidium iodide $(100 \mu \mathrm{g} / \mathrm{mL})$ and the slides were mounted with $25 \mu \mathrm{L}$ of the anti-fading Vectashield ${ }^{\mathbb{B}}$ Mounting Medium.

\section{Results}

A total of 24 specimens were cytogenetically analyzed. Specimens from all populations had a modal diploid number of 54, composed of metacentric and submetacentric chromosomes $(\mathrm{FN}=108)$ (Table 1 and Figure $2 \mathrm{a})$.

The different applied staining techniques produced a pattern common to specimens of both sexes from all the populations. C-banding analysis revealed the presence of large pericentromeric heterochromatic segments in all chromosomes and a block at the terminal region of a middle-sized chromosome pair (Figure 2b).

Silver nitrate and chromomycin $\mathrm{A}_{3}$ or mithramycin staining revealed the presence of two NOR-bearing chro- 
Table 1 - Diploid numbers found in Leporellus vittatus: populations from

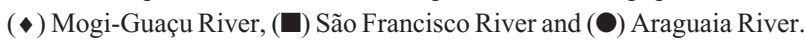

\begin{tabular}{|c|c|c|c|c|c|c|c|}
\hline \multirow[t]{2}{*}{ Specimens } & \multirow[t]{2}{*}{ Sex } & \multirow{2}{*}{$\begin{array}{c}\text { Total number } \\
\text { of cells }\end{array}$} & \multicolumn{5}{|c|}{ Diploid numbers } \\
\hline & & & 50 & 51 & 52 & 53 & 54 \\
\hline 10093 & M & 5 & - & - & - & - & 5 \\
\hline $10094(\diamond)$ & $\mathrm{F}$ & 8 & - & - & - & - & 8 \\
\hline $10095(\diamond)$ & M & 3 & - & - & - & - & 3 \\
\hline $10096(\bullet)$ & M & 38 & - & - & 1 & - & 37 \\
\hline $10097(\bullet)$ & M & 24 & - & - & - & - & 24 \\
\hline $10098(\bullet)$ & M & 25 & - & - & 1 & - & 24 \\
\hline $10102(\bullet)$ & M & 8 & - & - & 1 & - & 7 \\
\hline $10103(\bullet)$ & $\mathrm{F}$ & 15 & - & - & 1 & - & 14 \\
\hline $10104(\bullet)$ & F & 17 & - & - & - & - & 17 \\
\hline $10105(\bullet)$ & $\mathrm{F}$ & 6 & - & - & 1 & - & 5 \\
\hline $10106(\bullet)$ & $\mathrm{F}$ & 7 & - & - & - & - & 7 \\
\hline 10107 & F & 27 & - & - & 2 & - & 25 \\
\hline $10108(\bullet)$ & $\mathrm{U}$ & 10 & - & - & - & - & 10 \\
\hline $10109(\bullet)$ & $\mathrm{U}$ & 11 & - & 1 & - & - & 10 \\
\hline $10112(\bullet)$ & $\mathrm{U}$ & 16 & - & - & - & - & 16 \\
\hline $10113(\bullet)$ & $\mathrm{U}$ & 2 & - & - & - & - & 2 \\
\hline 10125 & F & 9 & - & 1 & - & - & 8 \\
\hline 5596 (ם) & M & 8 & - & - & - & - & 8 \\
\hline 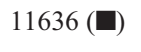 & F & 10 & - & - & - & - & 10 \\
\hline $13079(\square)$ & $\mathrm{F}$ & 41 & - & - & 1 & - & 40 \\
\hline 13087 (ם) & $\mathrm{F}$ & 132 & - & - & 2 & - & 130 \\
\hline $331(\bullet)$ & $\mathrm{F}$ & 67 & 1 & - & 4 & 1 & 61 \\
\hline $362(\bullet)$ & U & 2 & - & - & - & - & 2 \\
\hline $363(\bullet)$ & $\mathrm{U}$ & 8 & - & 1 & - & - & 7 \\
\hline
\end{tabular}

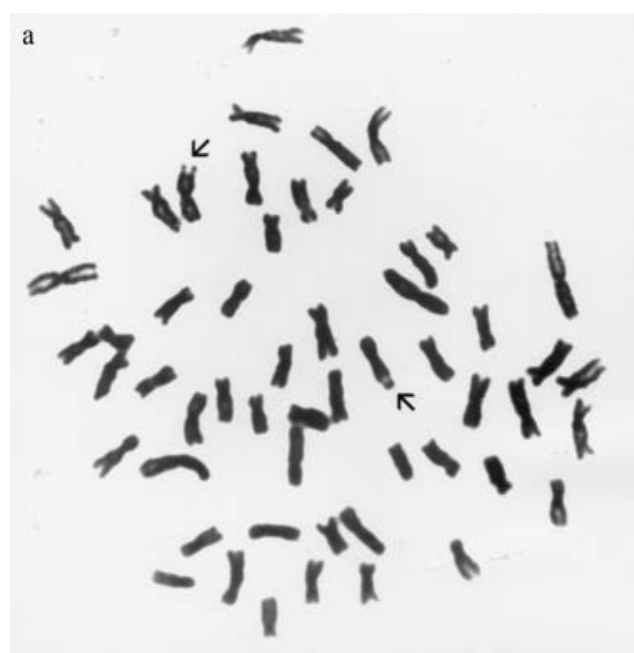

mosomes in this species (Table 2). The NOR sites were located near the telomere of the long arm of the mediumsized chromosome pair 12 and are apparently coincident with the conspicuous secondary constrictions, which appeared positive C-banded (Figure $3 \mathrm{a}$ and $3 \mathrm{~b}$ ). DAPI staining produced negative bands in these regions, while all the remaining chromosomes appear almost uniformly stained (Figure 3c).

The number of NORs and their unique location on chromosome pair 12 were further confirmed by FISH with

Table 2 - Frequencies of ribosomal genes bearing chromosomes in specimens from the distinct populations of Leporellus vittatus: ( Mogi-Guaçu River, (অ) São Francisco River and (•) Araguaia River.

\begin{tabular}{|c|c|c|c|c|c|c|c|c|}
\hline \multirow[t]{2}{*}{ Specimens } & \multicolumn{2}{|c|}{ Ag-NORs } & \multicolumn{2}{|c|}{$\begin{array}{c}\mathrm{CMA}_{3} \text { or } \\
\mathrm{MM}\end{array}$} & \multicolumn{2}{|c|}{$\begin{array}{c}\text { FISH (45S } \\
\text { rDNA) }\end{array}$} & \multicolumn{2}{|c|}{$\begin{array}{c}\text { FISH ( } 5 \mathrm{~S} \\
\text { rDNA) }\end{array}$} \\
\hline & 1 & 2 & 1 & 2 & 1 & 2 & 2 & 4 \\
\hline $10094(\bullet)$ & 0 & 84 & 1 & 13 & - & - & - & - \\
\hline $10096(\bullet)$ & 1 & 14 & 1 & 6 & - & - & - & - \\
\hline $10097(\bullet)$ & 1 & 29 & 2 & 75 & 7 & 156 & 141 & 0 \\
\hline 10098 & 3 & 45 & 2 & 105 & 8 & 92 & 92 & 0 \\
\hline 10103 & 0 & 4 & 2 & 8 & - & - & - & - \\
\hline $10104(\bullet)$ & 0 & 7 & 2 & 74 & 3 & 54 & 15 & 0 \\
\hline $10105(\bullet)$ & 0 & 10 & 0 & 6 & - & - & - & - \\
\hline 10107 ( ) & 1 & 23 & 1 & 105 & 6 & 210 & 67 & 0 \\
\hline 5596 (ם) & 1 & 27 & 0 & 30 & - & - & - & - \\
\hline $11636(\mathbf{\square})$ & 3 & 35 & 1 & 35 & 0 & 41 & 14 & 0 \\
\hline $13079(\mathbf{\square})$ & 1 & 33 & 0 & 34 & - & - & 16 & 0 \\
\hline 13087 (ם) & 4 & 168 & 0 & 200 & 5 & 237 & 290 & 0 \\
\hline $331(\bullet)$ & 2 & 75 & 3 & 174 & 5 & 211 & 0 & 288 \\
\hline $362(\bullet)$ & 0 & 14 & 0 & 12 & - & - & 0 & 33 \\
\hline $363(\bullet)$ & 0 & 8 & 0 & 5 & - & - & 0 & 8 \\
\hline
\end{tabular}

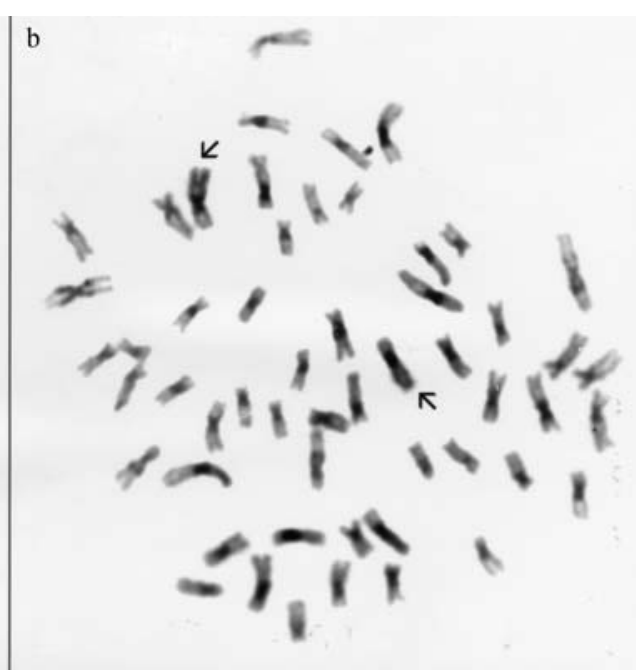

Figure 2 - Metaphase plate of Leporellus vittatus after Giemsa staining (a) and sequential C-banding (b). Arrows indicate the NOR-bearing chromosomes. 

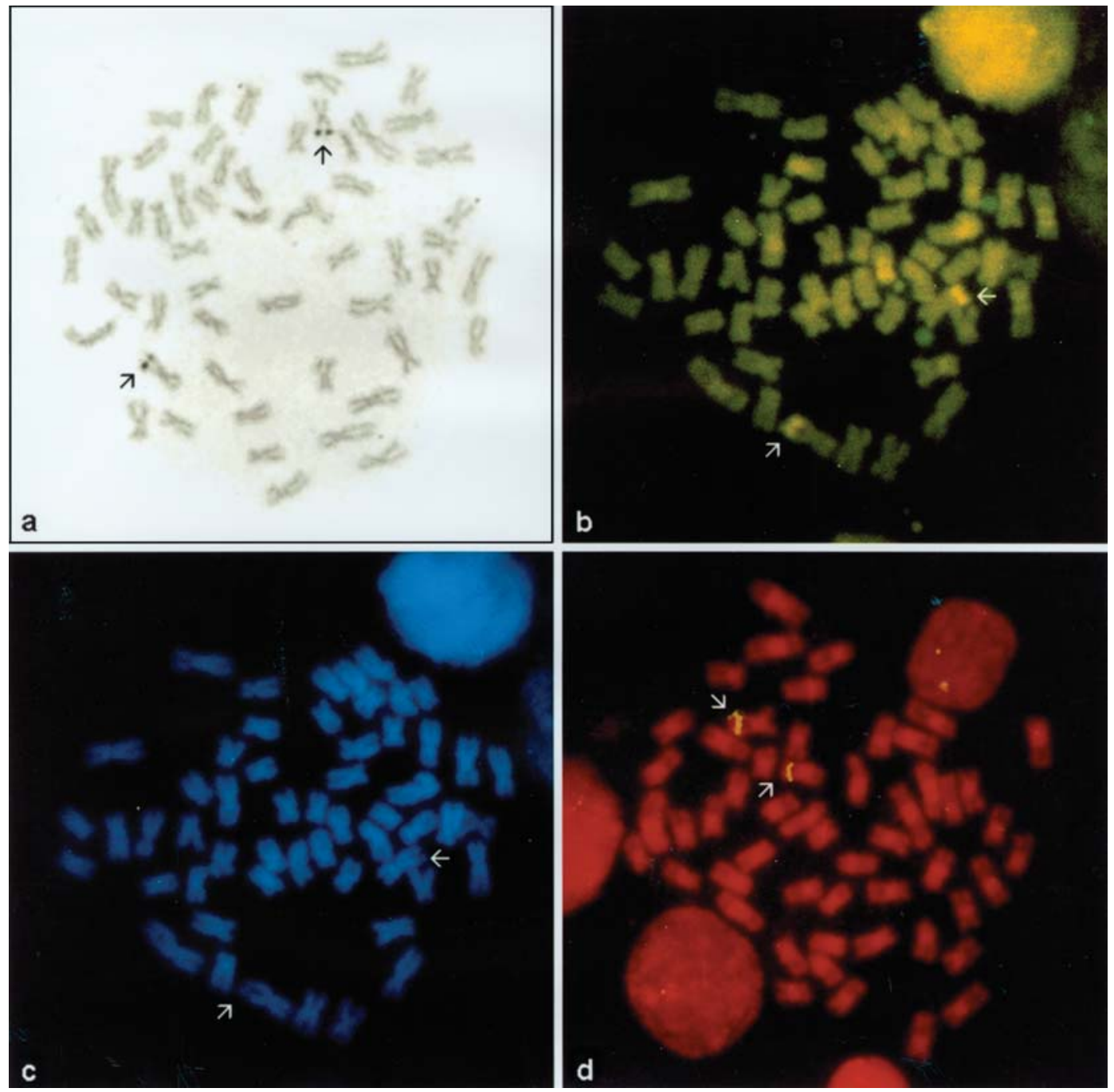

Figure 3 - Metaphase plates of Leporellus vittatus: silver staining (a); sequential $\mathrm{CMA}_{3}$ (b) and DAPI (c) staining; FISH with 45S ribosomal DNA probe (d). Arrows indicate the NOR-bearing chromosomes.

biotinylated $18 \mathrm{~S}$ and $28 \mathrm{~S}$ rDNA (45S rDNA) probes (Figure $3 \mathrm{~d})$.

The $5 \mathrm{~S}$ ribosomal genes were detected by FISH on chromosome pairs distinct from the ones bearing the $45 \mathrm{~S}$ rDNA clusters. In the specimens from the Paraná and São Francisco Basins the 5S rDNA clusters were interstitially located on the long arm of the $2^{\text {nd }}$ chromosome pair (Figure $4 \mathrm{a}$ and $\mathrm{b}$ ). The specimens from the Tocantins-Araguaia Basin showed two chromosome pairs bearing these sites. In this population the 5S rDNA sites were observed on the long arm of the $9^{\text {th }}$ chromosome pair and on the short arm of the $17^{\text {th }}$ chromosome pair (Figure $4 \mathrm{c}$ ).

\section{Discussion}

According to Buerlen (1970), the major drainage basins of Brazil began to develop during the Tertiary. Although the precise time of formation of each hydrographic system cannot be determined, several teleost fish species of the families Cichlidae, Characidae, and Curimatidae have been described as endemic of distinct hydrographic basins, reinforcing the supposed vicariant events (Kullander, 1983; Menezes, 1988; Vari, 1988).

The cytogenetic markers studied here included different banding techniques, fluorochrome staining, and in situ hybridization with ribosomal probes, allowing a careful investigation of the constitutive heterochromatin and, particularly, of the ribosomal sites, which are chromosomal regions often described as variable in fishes.

Although the three studied populations of Leporellus vittatus share the same karyotypic structure already described by Galetti et al. (1991) for the population from the Paraná Basin and no differences could be detected in the heterochromatin distribution pattern and in the number and location of the $45 \mathrm{~S}$ rDNA sites, interpopulation differences were evidenced concerning the number and location of the $5 \mathrm{~S}$ rDNA clusters.

The association between heterochromatin and NOR sites observed in all the three studied populations seems to 


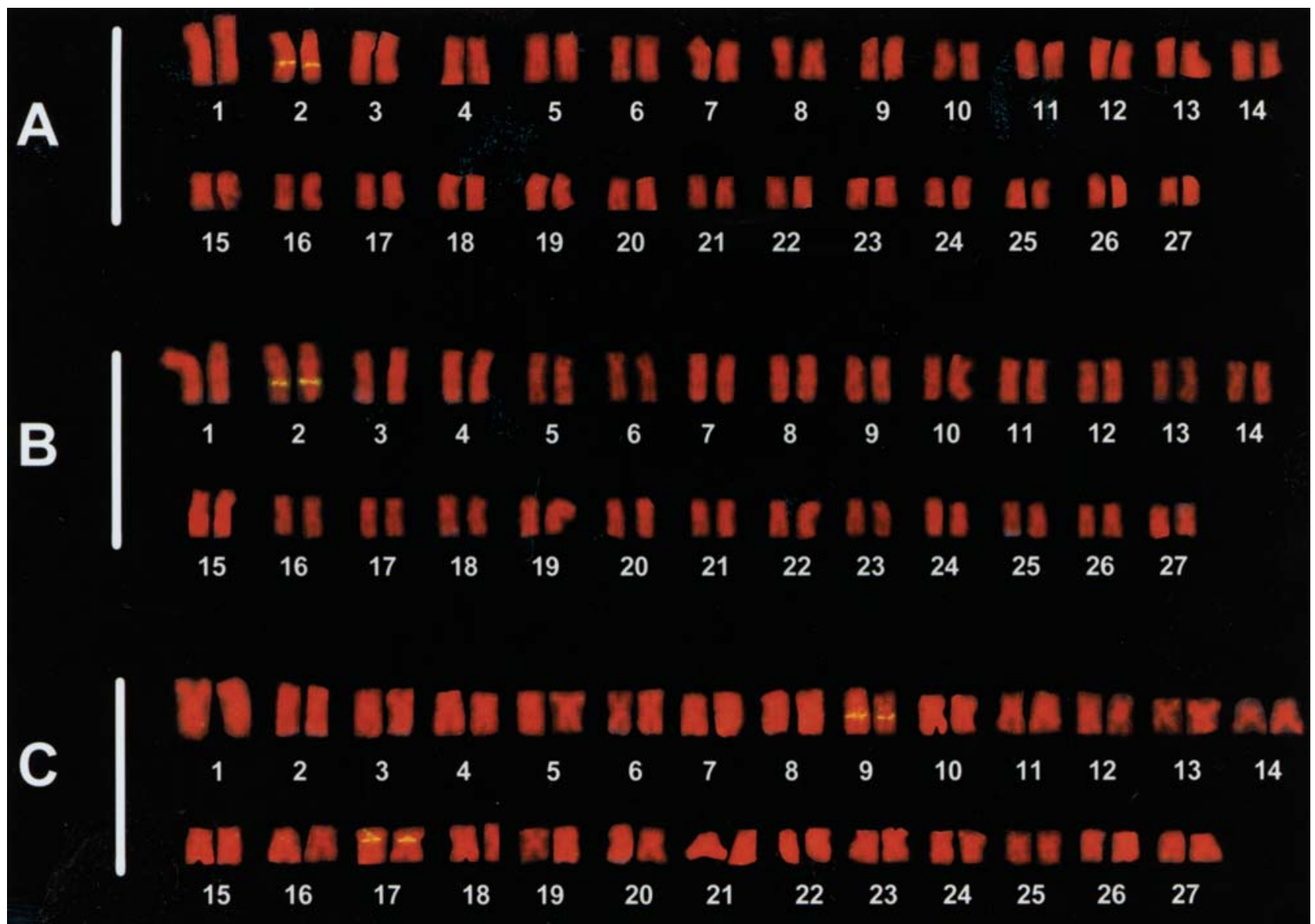

Figure 4 - Karyotypes of Leporellus vittatus: FISH with 5S ribosomal probe in specimens from Mogi-Guaçu (a), São Francisco (b) and Araguaia (c) Rivers.

be a common feature in fishes and has also been described for many other fish species (Galetti et al., 1991; Rossi et al., 1996; Aguilar and Galetti, 1997; Martins and Galetti, 1997). This NOR-associated heterochromatin, positive stained with $\mathrm{CMA}_{3}$, is thus GC-rich as originally reported by Amemiya and Gold (1986). DAPI staining, an ATspecific fluorochrome, confirmed the GC-rich nature of this heterochromatin, since negative bands coincident to the NOR sites were observed.

The lack of large chromosomal differences among the populations is not surprising since the karyotypic macrostructure of $L$. vittatus seems to be conserved among the Anostomidae (Galetti et al., 1981; Martins and Galetti, 1997, 1998) and other related Characiformes families, such as Curimatidae (Venere and Galetti, 1989; Feldberg et al., 1992), Parodontidae (Jesus and Moreira-Filho, 2000), and Prochilodontidae (Pauls and Bertollo, 1990), suggesting that the karyotype with $2 \mathrm{n}=54, \mathrm{FN}=108$, is ancient among the Characiformes.

Nevertheless, subtle changes in the chromosomal microstructure involving distinct rearrangements in the ribosomal regions seem to have occurred during the evolutionary diversification of the Anostomidae and may be strictly related to species differentiation. Intrapopulational chromosomal polymorphisms involving the number of $45 \mathrm{~S}$ rDNA sites have already been reported in Leporinus friderici and Leporinus trifasciatus (Galetti et al., 1991; Galetti et al., 1995a,b), despite the conserved chromosome structure $(2 \mathrm{n}=54, \mathrm{FN}=108)$. In the present study we identified differences in the number and location of the $5 \mathrm{~S}$ rDNA clusters among distinct populations of Leporellus vittatus from major Brazilian hydrographic basins.

In Neotropical characiform fishes, the 5S rDNA clusters are generally distributed in an interstitial position in two autosomal chromosome pairs and are usually not syntenic to the $45 \mathrm{~S}$ rDNA sites, suggesting that this could be a common condition for the 5S rRNA gene organization in the genome of these fishes (Martins and Galetti, 1999, 2000, 2001; Born and Bertollo, 2000).

However, variations concerning the number and location of 5S rDNA sites have already been described for many other fish species. Multiple sites have been described for some salmonid species that show up to eight sites located on distinct autosomal chromosome pairs (Fujiwara et al., 1998), and for Astyanax scabripinnis, a characid fish, that presents eight $5 \mathrm{~S}$ rDNA sites located on four distinct 
chromosome pairs (Ferro et al., 2000). The 5S rDNA clusters have also been located on the X or Y sex chromosomes of some salmonid species (Moran et al., 1996; Iturra et al., 2001; Stein et al., 2001), and on the Y-chromosome of the males of Chionodraco hamatus, an Antarctic fish (Mazzei et al., 2004). Frequently, differences in the number and position of 5S rDNA sites have been reported as good chromosome markers to discriminate closely related fish species, such as in some families of the orders Mugiliformes and Perciformes (Gornung et al., 2001; Molina and Galetti, 2002; Rossi et al., 2005). Accordingly, the interpopulation differences observed in the present study concerning the number and location of the 5S rDNA clusters between Paraná/São Francisco and Tocantins-Araguaia populations of $L$. vittatus suggest that the species currently named Leporellus vittatus may comprise a complex of cryptic species.

The recent discovery that, during the construction of the Furnas hydroelectric power dam in the upper Paraná River Basin in the early 1960s, the Piumhi River drainage outflow was diverted into the headwaters of the São Francisco River Basin has raised questioning about the current São Francisco watershed ichthyofauna structure (MoreiraFilho and Buckup, 2005). As this transposition event allowed the entire fish fauna of the Piumhi River and associated swamps, lakes, and tributaries to intermingle with the fish fauna of the São Francisco Basin, it may have contributed to the chromosomal stability described by many authors for Paraná and São Francisco Neotropical fish populations, as also described in the present study. Therefore, further studies comparing the different populations of $L$. vittatus and other anostomid species through molecular approaches, such as DNA sequencing of mitochondrial genes, may probably give a more precise answer to the present question - Is Leporellus vittatus a complex of cryptic species?

\section{Acknowledgments}

This work was supported by Coordenação de Aperfeiçoamento de Pessoal de Nível Superior (CAPES), Conselho Nacional de Desenvolvimento Científico e Tecnológico (CNPq) and Fundação Universitária José Bonifácio (FUJB).

\section{References}

Aguilar CT and Galetti Jr PM (1997) Chromosomal studies in South Atlantic serranids (Pisces, Perciformes). Cytobios 89:105-114.

Amemiya CT and Gold JR (1986) Chromomycin A 3 stains nucleolus organizer regions of fish chromosomes. Copeia 1:226231.

Bertollo LAC, Takahashi CS and Moreira-Filho O (1978) Cytotaxonomy considerations on Hoplias lacerdae (Pisces, Erithrynidae). Braz J Genet 1:103-120.
Born GG and Bertollo LAC (2000) An XX/XY sex chromosome system in a fish species, Hoplias malabaricus, with a polymorphic NOR-bearing X chromosome. Chrom Res 8:111118.

Buerlen K (1970) Geologie von Brasilien. Gebrüder Borntraeger, Berlin, 444 pp.

Cortadas J and Pavon MC (1982) The organization of ribosomal genes in vertebrates. EMBO J 1:1075-1080.

Feldberg E, Porto JIR and Bertollo LAC (1992) Karyotype evolution in Curimatidae (Teleostei, Characiformes) of Amazon region. I. Studies on the genera Curimata, Psectrogaster, Steindachnerina and Curimatella. Braz J Genet 15:369-383.

Fenocchio AS, Venere PC, Cesar ACG, Dias AL and Bertollo LAC (1991) Short term culture from solid tissues of fishes. Caryologia 44:161-166.

Ferro DAD, Neo DM, Moreira-Filho O and Bertollo LAC (2000) Nucleolar organizing regions, $18 \mathrm{~S}$ and 5S rDNA in Astyanax scabripinnis (Pisces, Characidae): Populations distribution and functional diversity. Genetica 110:55-62.

Fowler HW (1950) Os Peixes de Água Doce do Brasil. In: Arquivos de Zoologia do Estado de São Paulo, v. VI. Departamento de Zoologia da Secretaria da Agricultura, Indústria e Comércio, São Paulo, pp 205-404.

Fujiwara A, Abe S, Yamaha E, Yamazaki F and Yoshida MC (1998) Chromosomal localization and heterochromatin association of ribosomal RNA gene loci and silver-stained nucleolar organizer regions in salmonid fishes. Chrom Res 6:463-471.

Galetti Jr PM, Foresti F, Bertollo LAC and Moreira-Filho O (1981) Karyotypic similarity in three genera (Leporinus, Leporellus and Schizodon) of the family Anostomidae (Pisces, Teleostei). Braz J Genet 4:11-15.

Galetti Jr PM, Mestriner CA, Venere PC and Foresti F (1991) Heterochromatin and karyotype reorganization in fish of the family Anostomidae (Characiformes). Cytogenet Cell Genet 56:116-121.

Galetti Jr PM, Mestriner CA, Monaco PJ and Rasch EM (1995a) Post-zygotic modifications and intra- and inter-individual nucleolar organizing region variations in fish: Report of a case involving Leporinus friderici. Chrom Res 3:285-290.

Galetti Jr PM, Lima NRW and Venere PC (1995b) A monophyletic ZW sex chromosome system in Leporinus (Anostomidae, Characiformes). Cytologia 60:375-382.

Garavello JC and Britski HA (2003) Family Anostomidae (Headstanders). In: Reis RE, Kullander SO and Ferraris Jr CJ (eds) Check List of the Freshwater Fishes of South and Central America. 1st ed. EDIPUCRS, Porto Alegre, pp 71-84.

Gornung E, Cordisco CA, Rossi AR, Innocentiis DS, Crosetti D and Sola L (2001) Chromosomal evolution in Mugilidae: Karyotype characterization of Liza saliens and comparative localization of major and minor ribosomal genes in the six Mediterranean mullets. Mar Biol 139:55-60.

Howell WM and Black DA (1980) Controlled silver-staining of nucleolus organizer regions with a protective colloidal developer: A 1-step method. Experientia 36:1014-1015.

Iturra P, Lam N, De La Fuente M, Vergara N and Medrano JF (2001) Characterization of sex chromosomes in rainbow trout and coho salmon using fluorescence in situ hybridization (FISH). Genetica 111:125-131. 
Jesus CM and Moreira-Filho O (2000) Karyotypes of three species of Parodon (Teleostei, Parodontidae). Ichthyol Explor Freshwaters 11:75-80.

Kullander SO (1983) A revision of the South American cichlid genus Cichlasoma (Teleostei, Cichlidae). Swedish Museum of Natural History, Sweden, 296 pp.

Lande R (1979) Effective deme sizes during long-term evolution estimated from rates of chromosomal rearrangement. Evolution 33:234-251.

Martins C and Galetti Jr PM (1997) Narrow chromosome diversity in fish of the genus Schizodon (Characiformes, Anostomidae). Cytobios 92:139-147.

Martins C and Galetti Jr PM (1998) Karyotype similarity between two sympatric Schizodon fish species (Anostomidae, Characiformes) from the Paraguay River basin. Genet Mol Biol 21:355-360.

Martins C and Galetti Jr PM (1999) Chromosomal stability of 5S rDNA genes in Leporinus fish (Anostomidae, Characiformes). Chrom Res 7:363-367.

Martins C and Galetti Jr PM (2000). Conservative distribution of 5S rDNA loci in Schizodon (Pisces, Anostomidae) chromosomes. Chrom Res 8:353-355.

Martins C and Galetti Jr PM (2001) Two 5S rDNA arrays in Neotropical fish species: Is it a general rule for fishes? Genetica 111:439-446

Mazzei F, Ghigliotti L, Bonillo C, Coutanceau JP, Ozouf-Costaz $\mathrm{C}$ and Pisano E (2004) Chromosomal patterns of major and $5 \mathrm{~S}$ ribosomal DNA in six icefish species (Perciformes, Notothenioidei, Channichthyidae). Polar Biol 28:47-55.

Menezes NA (1988) Implications of the distribution patterns of the species of Oligosarcus (Teleostei, Characidae) from Central and Southern South America. In: Vanzoline PE and Ronald Heyer W (eds) Proceedings of a Workshop on Neotropical Distribution Patterns. Academia Brasileira de Ciências, Rio de Janeiro, pp 295-304.

Molina WF and Galetti Jr PM (2002) Robertsonian rearrangements in the reef fish Chromis (Perciformes, Pomacentridae) involving chromosomes bearing 5S rRNA genes. Genet Mol Biol 25:373-377.
Moran P, Martinez JL, Garcia-Vazquez E and Pendas AM (1996) Sex chromosome linkage of $5 \mathrm{~S}$ rDNA in rainbow trout (Oncorhynchus mykiss). Cytogenet Cell Genet 75:145-150.

Moreira-Filho O and Buckup PA (2005) A poorly known case of watershed transposition between the São Francisco and upper Paraná River basins. Neotrop Ichthyol 3:449-452.

Pauls E and Bertollo LAC (1990) Distribution of supernumerary chromosome system and aspects of karyotypic evolution in the genus Prochilodus (Pisces, Prochilodontidae). Genetica 81:117-123.

Pinkel D, Straume T and Gray JW (1986) Cytogenetic analysis using quantitative, high sensitivity, fluorescence hybridization. Proc Nat Acad Sci USA 83:2934-2938.

Rossi AN, Crossetti D, Gornung E and Sola L (1996). Cytogenetic analysis of global populations of Mugil cephalus (striped mullet) by different staining techniques and fluorescent in situ hybridization. Heredity 76:77-82.

Rossi AR, Gornung E, Sola L and Nirchio M (2005) Comparative molecular cytogenetic analysis of two congeneric species, Mugil curema and M. liza (Pisces, Mugiliformes), characterized by significant karyotype diversity. Genetica 125:27-32.

Schmid M (1980) Chromosome banding in Amphibia IV. Differentiation of GC- and AT-rich chromosome regions in Anura. Chromosoma 77:83-103.

Schweizer D, Ambros P and Andrle M (1978) Modification of DAPI banding on human chromosomes by pre-staining with a DNA binding oligopeptide antibiotic distamycin A. Expl Cell Res 111:327-332.

Stein J, Phillips RB and Devlin RH (2001) Identification of the Y chromosome in chinook salmon (Oncorhynchus tshawytscha). Cytogenet Cell Genet 92:108-110.

Sumner AT (1972) A simple technique for demonstrating centromeric heterocromatin. Expl Cell Res 75:304-306.

Vari RP (1988) The Curimatidae, a lowland Neotropical fish family (Pisces, Characiformes): Distribution, endemism and phylogenetic biogeography. Proceedings of a Workshop on Neotropical Distribution Patterns, pp 313-348.

Venere PC and Galetti Jr PM (1989) Chromosome evolution and phylogenetic relationships of some Neotropical Characiformes of the family Curimatidae. Brazil J Genet 12:17-25.

Associate Editor: Lurdes Foresti de Almeida-Toledo

License information: This is an open-access article distributed under the terms of the Creative Commons Attribution License, which permits unrestricted use, distribution, and reproduction in any medium, provided the original work is properly cited. 